\title{
Changes in sediment seed-bank composition of invaded macrophyte communities in a thermal river
}

\author{
Anna E. Vojtkó ${ }^{1}$ (D) | Attila Mesterházy ${ }^{2}$ | Kristóf Süveges ${ }^{3}$ | Orsolya Vallkó ${ }^{4}$ | \\ 1 Balázs A. Lukács ${ }^{1}$
}

${ }^{1}$ Department of Tisza Research, MTA Centre for Ecological Research - DRI, Debrecen, Hungary

${ }^{2}$ Celldömölk, Hungary

${ }^{3}$ Department of Botany, University of Debrecen, Debrecen, Hungary

${ }^{4}$ MTA-DE Biodiversity and Ecosystem Services Research Group, Debrecen, Hungary

\section{Correspondence}

Anna E. Vojtkó, Department of Tisza Research, MTA Centre for Ecological Research - DRI, Debrecen, Hungary. Email: vojtko.anna@okologia.mta.hu

Funding information

European Union; State of Hungary; European Social Fund, Grant/Award Number: TÁMOP-4.2.4.A/2-11/1-20120001, GINOP-2.3.2-15-2016-00019; OTKA, Grant/Award Number: PD120775, K108992

\section{Abstract}

1. Thermal waters, characterised by high water temperatures throughout the year, harbour a special flora atypical of temperate climatic conditions that are adapted to the combination of high water temperatures and low oxygen and carbonate contents. However, these ecosystems are susceptible to the invasion of tropical macrophytes because conditions in thermal waters are similar to those of in warmer latitudes.

2. We studied the vegetation and viable seed bank in an alien-dominated upstream section of a thermal river in Hungary, and a native-dominated downstream section of the same river where temperature was cooler and less stable. Our hypotheses were as follows: (1) alien and native plant species are clearly separated along the river, and this separation is driven by environmental factors (water temperature, conductivity and sediment characteristics) and (2) the species composition of seed banks reflects that of the established macrophytes, and thus, the seed-bank composition would differ in the up- and downstream reaches.

3. We defined 20 sampling units in two sections of the Hévíz River in West Hungary. The vegetation was surveyed in every sampling unit, and environmental variables (sediment and water) were recorded. Five sediment cores were taken from each sampling unit and incubated in a greenhouse under waterlogged conditions.

4. The mean seed-bank density was lower than any of the previously published values for aquatic plant communities. In total, fewer species germinated from the seed bank than the number of species observed in the vegetation. Moreover, the Sørensen similarity index, comparing the vegetation and seed-bank species composition, was extremely low. The lowest seed-bank density and diversity were detected in the alien-dominated upstream river section, where significantly fewer native species were present in the seed bank.

5. Despite favourable conditions for alien macrophytes to establish in this thermal river, they did not build up considerable persistent seed banks. We conclude that the dominance of aliens modified the species composition of both the vegetation and the seed bank, mainly by depleting the seed bank of native species. Therefore, future efforts to restore native vegetation from the seed bank may require a number of different strategies. 


\section{KEYWORDS}

alien species, aquatic plant, biological invasion, hydrophyte, neophyte

\section{1 | INTRODUCTION}

Inland waters harbour a large number of macrophytes that are rare or threatened (Nicolet et al., 2004), and these plants contribute to freshwater biodiversity at the regional level (Williams et al., 2004). However, they are threatened by habitat degradation and eutrophication (Sand-Jensen, Riis, Vestergaard, \& Larsen, 2000). Thermal rivers are a hotspot for unique aquatic flora in Central Europe. Because of their year-round high temperatures these rivers can provide suitable habitat for invasive aquatic plants originating from biomes with a warmer climate, such as the tropics or subtropics (Lukács et al., 2015). Due to this susceptibility to invasion, the biodiversity of ther mal waters is at risk; hence, improved knowledge of alien macrophyte establishment is needed for effective conservation and ecosystem management.

Thermal rivers are characterised by low oxygen and carbonate contents, as well as high temperatures throughout the year. The higher temperatures may expand the length of the growing season and positively affect growth rates and the timing of flowering and fruiting in native macrophyte species (Haag \& Gorham, 1977; Santamaria \& van Vierssen, 1997). Furthermore, these special environmental conditions make thermal rivers highly prone to the establishment of frost-sensitive plants (Hussner \& Lösch, 2005; Šajna, Haler, Škornik, \& Kaligarič, 2007), including several alien species that are considered to be serious threats to biodiversity.

Tropical and subtropical macrophytes have generally been introduced into temperate climate zones for horticultural or aquarium trade (Lukács, Mesterházy, Vidéki, \& Király, 2014; Šajna et al., 2007), which causes problems all over Europe (Brunel, 2009; Champion, Clayton, \& Hofstra, 2010) and North America (Maki \& Galatowitsch, 2004). Imported ornamental plants pose risks to wildlife when escaping from garden ponds to natural habitats. Several studies have found that alien macrophytes can decrease the diversity of native plants by competitive exclusion or by increasing the rate of eutrophication, as the night-time dissolved oxygen concentration can decline severely in the vicinity of dense populations (e.g. the invasion of Pistia stratiotes, Šajna et al., 2007; Azolla filiculoides, Espinar, Díaz-Delgado, Bravo-Utrera, \& Vilà, 2015; Vallisneria spiralis and P. stratiotes, Hussner, 2014). Based on predicted climate change scenarios, the climate will be warmer and drier in many parts of the temperate zone, which will likely facilitate the colonisation of even non-thermal waterbodies by tropical and subtropical alien macrophytes. These species can easily enter waterbodies via epi- or endozoochorous dispersal by waterfowl (Brochet, Guillemain, Fritz, Gauthier-Clerc, \& Green, 2009). Warm temperatures during winter might open "windows of opportunity": more tropical and subtropical species can overwinter even in non-thermal waterbodies by forming dense mats before the spring establishment of submerged native macrophytes (see, e.g. the case of A. filiculoides in the study by Espinar et al., 2015). To estimate the potential of tropical and subtropical macrophytes to invade and establish in temperate climates, even in nonthermal waterbodies, it is crucial to study their persistence traits, such as their ability to produce persistent seed banks.

Seed banks are of crucial importance in vegetation dynamics (Fenner \& Thompson, 2005). Studying the seed banks of invaded communities is a key issue because the legacy of plant invasions largely depends on (1) the ability of native species to buffer against their displacement from the above-ground vegetation and (2) the persistence of alien species in a community (Gioria \& Pyšek, 2016). Both factors are strongly related to the seed-bank characteristics of the native and alien species present and are crucial determinants of the resilience and long-term invasibility of communities. In their comprehensive study about species traits of invasive and native vascular plant species in north-western Europe, Thompson, Hodgson, and Rich (1995) found that aliens have less persistent seed banks, i.e. seeds in the lower sediment layer (Fenner \& Thompson, 2005), than spreading native species. Gioria and Pyšek (2016) found that the seed density of alien species can vary from very low to very high in invaded communities depending on the reproductive strategy of the invaders and several characteristics of the invaded habitat.

The density of seeds in persistent seed banks and the similarity between the current vegetation and seed banks are largely affected by successional stages, community stability and disturbance regimes, reflecting that seed banks may play different roles in the vegetation dynamics of different plant communities (Bossuyt \& Honnay, 2008; Hopfensperger, 2007). Many studies have found that both seed density and the similarity between vegetation and seed banks are lower in relatively stable habitats (Bossuyt \& Honnay, 2008; Valkó et al., 2014), where traits associated with successful establishment are generally more important than effective dispersal in time and space (Bossuyt \& Honnay, 2008; Brown \& Oosterhuis, 1981). Thermal waters have well-balanced temperatures throughout the year and can be considered stable habitats in this respect; thus, the total seed density and similarity between vegetation and seed banks should be low. However, it remains unknown whether alien macrophyte species can build up persistent seed banks in such habitats. It is crucial to answer this question in order to develop proper strategies for the long-term suppression of these species.

In aquatic environments, propagule banks represent the sum of various reproductive organs, not only seeds but also asexual propagules (Poiani \& Johnson, 1989). It is generally accepted that reproduction by seeds is of secondary importance in the case of macrophytes and that populations are maintained mainly by vegetative reproduction. However, several studies have highlighted the significance of 
seed banks in various community dynamics, such as the colonisation of habitats, population maintenance (McMillan, 1988; Terrados, 1993) and community re-establishment (Bonis \& Lepart, 1994; Grillas et al., 1993; Leck \& Simpson, 1987). Moreover, knowledge on the relationship between soil seed banks and above-ground vegetation can help conservation efforts managing exotic species and restoring habitats (Hopfensperger, 2007; Ma, Zhou, \& Du, 2010).

In most studies undertaken on the seed banks of aquatic vegetation, their composition was analysed in relation to either the vegetation or the water and sediment depth in order to determine the potential to rehabilitate species and habitats. In this study, we provide a detailed analysis of the viable seed banks of native and alien macrophytes in relation to the vegetation along a thermal river in Hungary that showed a gradient from warm and relatively stable temperatures upstream to cooler temperatures downstream. Specifically, we formulated the following hypotheses: (1) alien and native plant species will be clearly separated along the river, and this separation is driven by environmental factors (water temperature, $\mathrm{pH}$ and sediment characteristics); (2) the species composition of seed banks reflects that of the established macrophytes, and thus seed-bank composition will differ in up- and downstream reaches.

\section{MATERIALS AND METHODS}

\subsection{Study site}

The study was carried out in a thermal river in Hévíz, West Hungary $\left(46^{\circ} 47^{\prime} \mathrm{N}, 17^{\circ} 11^{\prime} \mathrm{E}\right)$, which is a natural but canalised small river with a constant water level. As the river originates from a thermal lake, the water temperature, conductivity and $\mathrm{pH}$ are approximately constant throughout the year at the upstream site (Figures 1 and 2), but temperatures are cooler downstream. The oxygen content, which is temperature dependent, shows constant values in upstream reaches but varies downstream due to the effects of water temperature, turbulence and vegetation cover (see Figure 1). The total river length is c. $13 \mathrm{~km}$, and the river flows at an elevation range 113-104 $\mathrm{m}$ a.s.l. The annual rainfall is estimated to be $650-700 \mathrm{~mm}$ with a mean annual temperature of $10-11^{\circ} \mathrm{C}$ in the surrounding area. The thermal lake and the river attract attention from tourists and nature conservationists, and the latter monitor and manage the area while the former use the lake as a spa. The thermal lake is nationally protected and is part of a nature reserve. The thermophilous vegetation of the river is characterised by native and alien hydrophytes (submerged and emergent) and predominantly native helophyte vegetation.

Although the historic vegetation of the lake and the river is less known, it has been confirmed that after the lake began to serve as a spa, it was also utilised for horticultural purposes (Boros, 1937; Szabó, 2002). The first description of the vegetation in the lake and its surroundings was provided during the 18th century (Lukács, 1943). According to this investigation, we assumed that the original vegetation of the river harboured several associations, such as Myriophyllo-Potametum, Hydrochari-Stratiotetum, Schoenetum nigricantis, Juncetum subnodulosi, Agrostetum albae, Festucetum pratensis, ScirpoPhragmitetum and Salicetum cinereae. Presently, Myriophyllo-Potametum communities dominate the middle and lower parts of the river. During the 19th century, tropical Nymphaea species and Nymphaea cultivars were planted in the lake for ornamental purposes (Lovassy, 1908). During the 1980s, aquarium plants were cultivated in the river, and community composition has been stable since that time.

\section{2 | Vegetation survey and environmental conditions}

We established 20 sampling plots $(2 \times 2 \mathrm{~m}$ each) randomly in the littoral zone of the Hévíz River. As the distribution of alien species is uneven along the river, we established 10 plots in the upper section
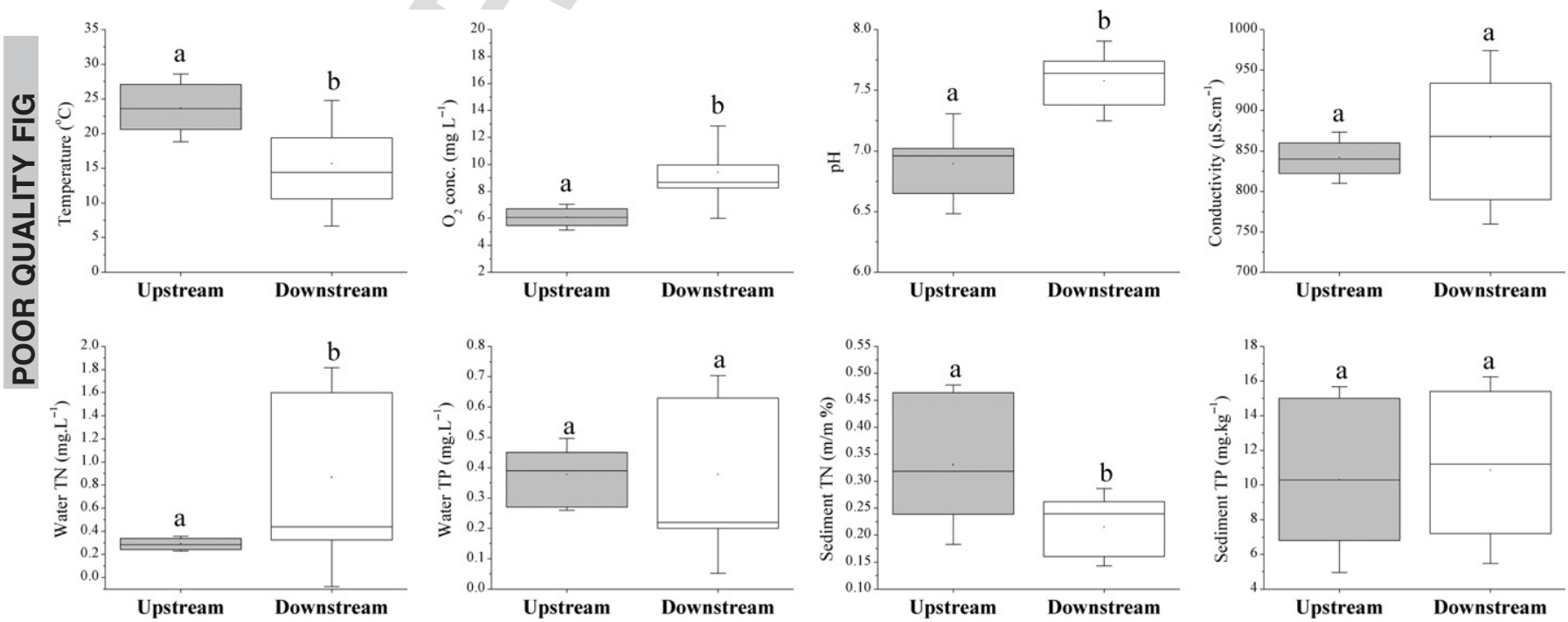

8 FIGURE 1 Boxplots of environmental variables measured in the upstream and downstream plots. Whiskers represent standard deviations. 


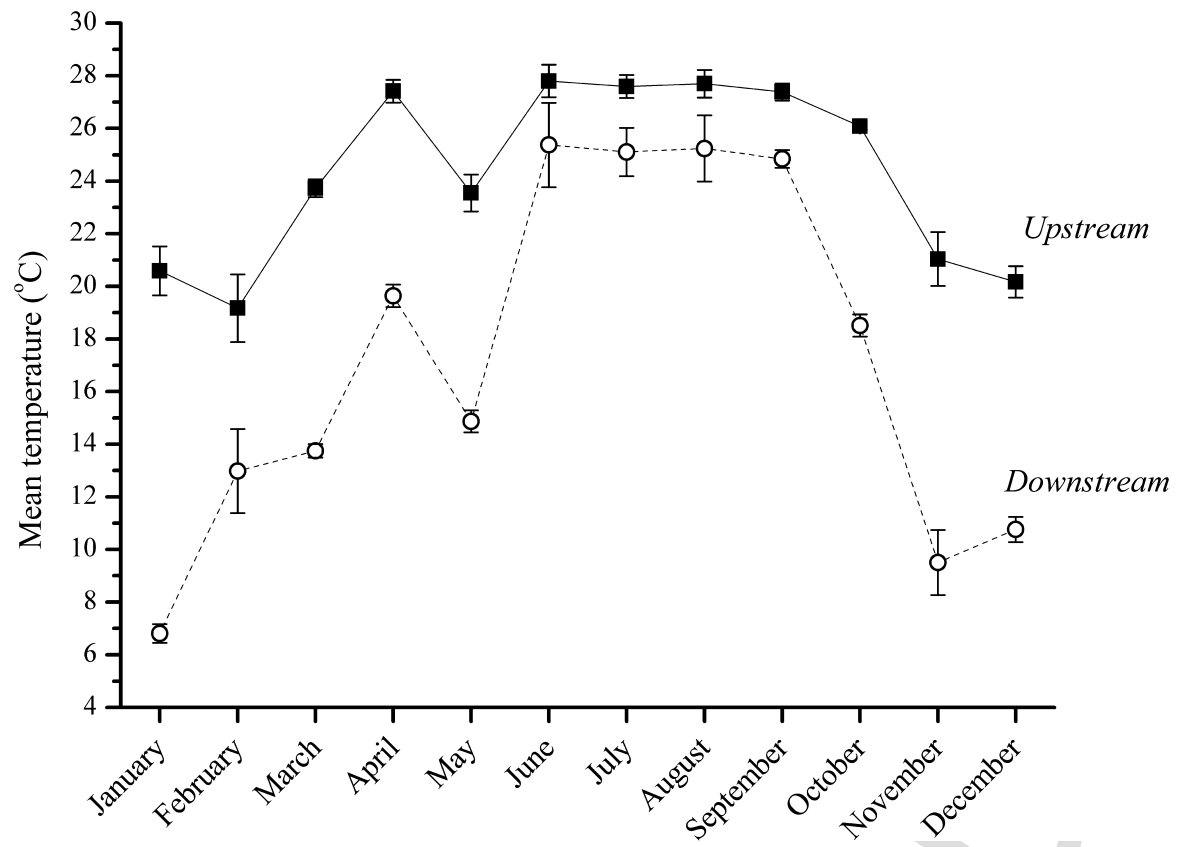

FIGURE 2 Variation in mean water temperature of upstream and downstream plots in 2013. Whiskers represent standard deviations of the river (hereafter upstream) and 10 plots in the lower section (hereafter downstream). The distance between the upstream and downstream sections amounts to $9.5 \mathrm{~km}$ along the channel. The percentage cover of vascular plants was recorded in each plot in August 2013. We collected one sediment and one water sample from each plot in August 2013 to estimate the total nitrogen (hereafter TN) and total phosphorous (hereafter TP) concentrations of the sediment and water, which are reliable proxies for habitat fertility. TN and TP were determined after Kjeldahl digestion using a Shimadzu UV-2600 UV-Vis spectrophotometer (Shimadzu, Kyoto, Japan) in the Hertelendi Laboratory of Environmental Studies of the Hungarian Academy of Sciences. TN was determined as ammonium while TP was determined as orthophosphate according to the standards of MSZ EN 14672 (2006) and MSZ EN 16168 (2013). We measured water temperature, conductivity, oxygen content and $\mathrm{pH}$ using an HQ40d portable multiparameter meter (Hach, Loveland, Colorado, U.S.A.) in every plot monthly for 1 year to detect any fluctuations in water characteristics.

\section{3 | Seed-bank sampling and germination}

Viable seed banks were analysed with the seedling emergence method (Poiani \& Johnson, 1988). Five sediment cores $(7 \mathrm{~cm}$ in diameter and $10 \mathrm{~cm}$ in depth) were taken from every plot in February 2014 using a tube-shaped bottom sampler (Hydro-Bios, Altenholz, Germany) following the sampling design of Boedeltje, Bakker, and ter Heerdt (2003). The number of cores per plot in that study is the minimum value of cores used in such studies and, due to the smaller size of our sampling plots $\left(4 \mathrm{~m}^{2}\right)$ compared to the plot sizes $\left(25 \mathrm{~m}^{2}\right)$ typically used by others, we considered that five cores were sufficient. Cores were aligned transversely in the channel from the border of the hydrophyte-helophyte transitional zone along the hydrophyte vegetation zone. The applied method (number of sediment cores per plot) and sampling design follow the standards of aquatic plant studies.

The core samples were divided in the field into sub-cores according to the upper $5 \mathrm{~cm}$ and lower $5 \mathrm{~cm}$ layer to identify the seed-bank strategy of the species. Samples were kept at $4^{\circ} \mathrm{C}$ until preparation. Sub-cores from the same plot were pooled, resulting in one upper and one lower sample per plot. The seed-bank samples were concentrated (ter Heerdt, Verweij, Bekker, \& Bakker, 1996) by washing them over sieves with 3 and $0.2 \mathrm{~mm}$ mesh sizes. The small mesh sizes used in the concentration process enabled us to exclude vegetative propagules of the majority of macrophyte species from the concentrated samples. However, we cannot fully exclude the possibility that some of the tiny propagules of Lemna species were included in the filtered material. The concentrated samples were spread in a 5- to $10-\mathrm{mm}$ thick layer on trays previously filled with a 1:1 mixture of steam-sterilised potting soil and sand, as recommended by Boedeltje, ter Heerdt, and Bakker (2002). All trays were submerged in distilled water in an unheated greenhouse under natural light and kept submerged until no extra hydrophyte species emerged. Next, all trays were kept under waterlogged conditions by refilling with distilled water if needed to ensure the germination of helophyte species. The greenhouse experiment was performed from April to late October 2014. The temperature of the greenhouse and the temperature of the water in the greenhouse were suitable for the germination of both alien and native species, as it reached the temperature of the original sampling sites. The total number of sunny hours was 1,743 (i.e. 385 cooling degree days using $19^{\circ} \mathrm{C}$ as the base temperature) during the germination period ( $\mathrm{KSH}, 2014)$. The daily minimum air temperature in the greenhouse ranged between $10^{\circ} \mathrm{C}$ (in April) and $26^{\circ} \mathrm{C}$ (in July), and the daily maximum air temperature ranged between $12^{\circ} \mathrm{C}$ (in October) and $41^{\circ} \mathrm{C}$ (in July). 


\subsection{Data analysis}

To compare the environmental variables and the vegetation and seed-bank characteristics of the plots between the upstream and downstream sections, one-way ANOVA and subsequent Tukey's tests were conducted using plot-level scores. The seed-bank data were analysed for the upper and lower sub-cores $(0-5 \mathrm{~cm}, 5-10 \mathrm{~cm})$ separately and for the whole profile $(0-10 \mathrm{~cm})$. Species densities in the seed bank were calculated as the number of germinated seeds per $\mathrm{m}^{2}$. Germinated Carex individuals died before developing diagnostic features that would have permitted species identification, and thus they were pooled with native Carex spp. in the analyses.

The diversity of the vegetation and the seed bank was calculated by using In-based Shannon diversity. Similarities in the species composition of the vegetation and seed bank of the same plot were expressed using Sørensen similarity (Legendre \& Legendre, 1998). Univariate statistics were calculated using the STATISTICA 8 software (StatSoft Inc., Tulsa, OK, U.S.A.). We applied redundancy analyses (RDA) to examine the correlation between the species composition (vegetation and seed bank separately) and environmental variables (mean water temperature, mean $\mathrm{pH}$, mean conductivity, mean water oxygen content, TN of water, TN of sediment, TP of water and TP of sediment) using CANOCO 5.04 (ter Braak \& Šmilauer, 2012). Significance tests of the RDAs were conducted using a Monte Carlo permutation test (ter Braak \& Šmilauer, 2012). Spearman rank correlation was used to analyse the relationship between vegetation and seed-bank characteristics and environmental variables (Zar, 1999).

\section{3 | RESULTS}

\section{1 | Vegetation and seed-bank characteristics in relation to environmental conditions}

The RDA analyses revealed clear separation of the upstream and downstream sections, both in environmental characteristics and species composition (vegetation and seed-bank species composition separately) (Figure 3). Higher water temperature, conductivity and sediment TN differentiated the upstream plots from the downstream ones. The explanatory variables accounted for $79.2 \%$ (adjusted $64.1 \%$ ) of the total variation in the vegetation and for $63.6 \%$ (adjusted $37.1 \%$ ) in the seed bank. Temperature and $\mathrm{pH}$ had significant effects on the distribution of the vegetation, while temperature affected seed-bank species composition.

We found significant correlations between the environmental variables and both the vegetation and seed-bank characteristics (see Table S1). None of the vegetation variables was significantly correlated with the sediment variables. The Shannon diversity of helophyte species in the vegetation increased significantly with higher water temperature, while it decreased with higher oxygen content and $\mathrm{pH}$. Hydrophyte species diversity decreased significantly with higher water temperature and conductivity, while it increased significantly in oxygen-rich water. The diversity of native species showed a negative relationship with water temperature and conductivity, while it increased with higher water oxygen content. Alien species diversity decreased with higher water $\mathrm{TN}$, oxygen content and $\mathrm{pH}$, while it increased with higher water temperature and conductivity. In the seed bank, helophyte species diversity decreased with higher sediment TN, water temperature and conductivity, while it increased with higher water $\mathrm{TN}$, oxygen content and $\mathrm{pH}$. Hydrophyte species diversity in the seed bank decreased with higher water temperature and increased with higher $\mathrm{pH}$. The diversity of the germinated native species decreased with higher sediment $\mathrm{TN}$, water temperature and conductivity and increased with higher water TN, oxygen content and $\mathrm{pH}$ (Table S1).

\subsection{Vegetation and seed-bank characteristics}

Altogether, we found 34 species in the vegetation (26 native, 8 alien) and 19 species in the seed bank (17 native, 2 alien). Seven species were present both in the vegetation and the seed bank, while 27 species were found only in the vegetation and 12 species were present only in the seed bank (Table 1).

In the upstream plots, 21 species occurred in the vegetation (13 native, 8 alien). Seven macrophyte species appeared in the seed bank ( 5 native, 2 alien), all of which had seeds in the upper sediment layer $(0-5 \mathrm{~cm})$ but only four in the lower layer $(5-10 \mathrm{~cm})$. Native Chara vulgaris had the highest seed density both in the upper and lower sediment layers, which contributed from $4 \%$ to $100 \%$ of the total seed bank. Other macrophytes either had especially high seed densities (e.g. native Nymphaea alba and Lemna minor) or had no significant seed bank (e.g. Typha angustifolia). Among the alien species, only Rotala rotundifolia and Bacopa crenata appeared in the seed bank.

In the downstream plots, 19 species occurred in the vegetation (17 native, 2 alien). In the seed bank, 16 species were present altogether (16 native, 0 alien), among which all had seeds in the upper layer but only 10 in the lower layer. The most abundant species in the seed bank were the native Lemna minor, Typha angustifolia and Juncus inflexus. The highest seed density was found for Nymphaea alba, Najas minor and Alisma plantago-aquatica, while other species had no significant seed bank.

The mean Sørensen similarity index scores of the vegetation and seed bank were 0.04 in the upstream plots and 0.11 in the downstream plots (Table 2), indicating a weak relationship between the compositions of the seed bank and established vegetation. Both mean seed density and species richness in the whole sediment profile $(0-10 \mathrm{~cm})$ and upper sediment layers $(0-5 \mathrm{~cm})$ differed significantly between the up- and downstream plots, with values in the upstream plots being significantly lower (ANOVA, $p<.05$ ). However, densities and richness of seeds in the lower sediment layer $(5-10 \mathrm{~cm}$ ) did not differ significantly (ANOVA, $p>.05$ ) between the two reaches (Figure 4).

Hydrophyte, helophyte, native and total species richness in the seed bank were significantly and consistently lower in the upstream plots, as were total, helophyte and native species seed-bank 

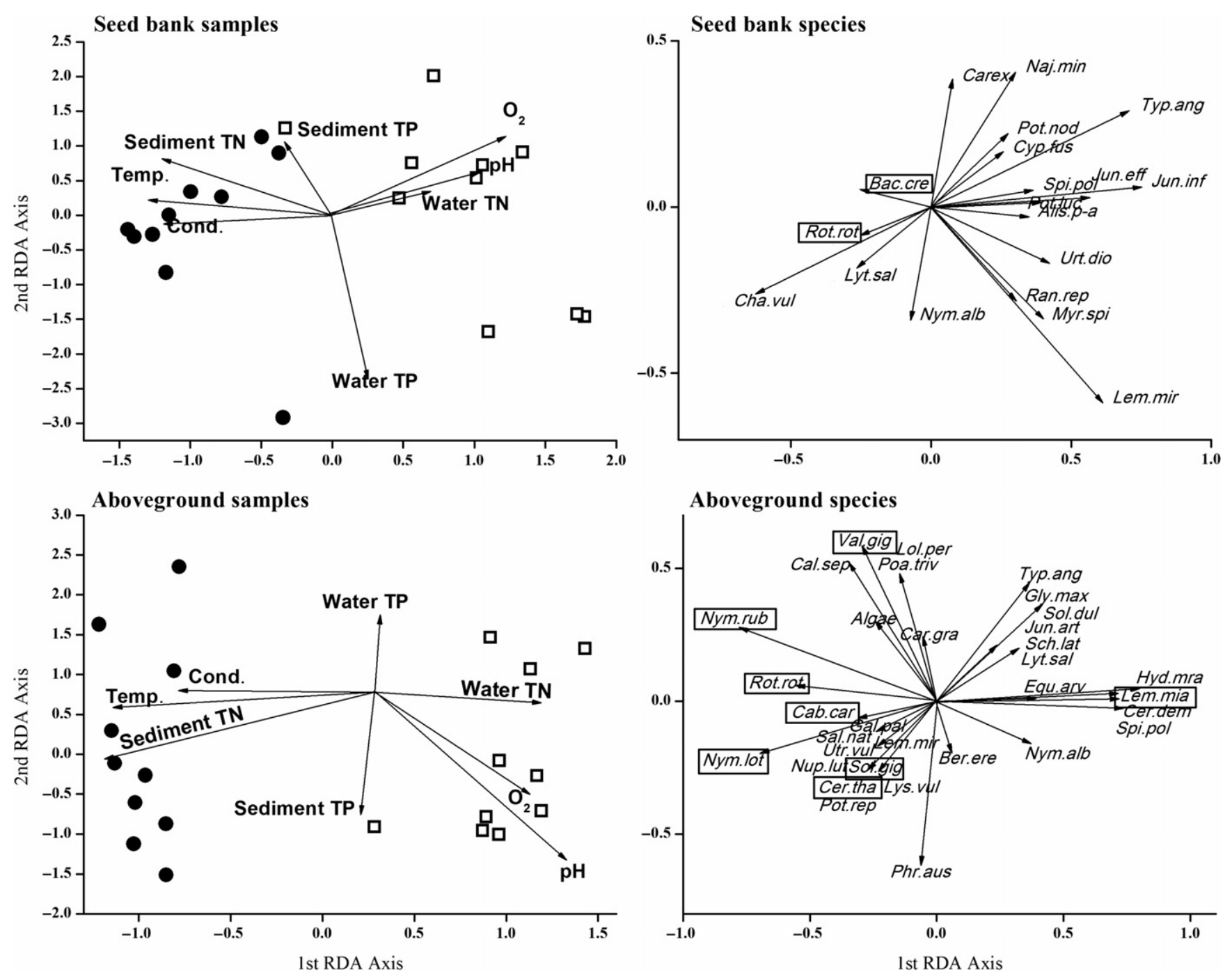

\section{$\square$ Downstream plots Upstream plots}

FIGURE 3 Redundancy analyses of the effect of environmental variables on the above-ground vegetation and seed-bank species composition of the upstream and downstream plots. The ordination is based on species abundance data. TN = total nitrogen; TP = total phosphorous; Cond. = conductivity; Temp. = temperature. Species are abbreviated using the first three letters of their genus and species names. Lemna minor is abbreviated as Lem.mir, and Lemna minuta is abbreviated as Lem.mia. Alien species are indicated with framed species names

densities (Table 2). However, there was no significant difference between up- and downstream seed banks in terms of in total species richness, helophyte species richness or in terms of the cover of helophytes and hydrophytes. Furthermore, there was no difference in alien species number or in the seed density of hydrophytes and alien species, although the highest seed density and diversity were recorded in downstream plots.

\section{4 | DISCUSSION}

We studied the characteristics of the vegetation and the seed bank in up- and downstream reaches of a thermal river in Hungary that harboured alien and native aquatic plants. The results partly confirmed our first hypothesis. We found that alien species of macrophytes dominated upstream, while in the downstream section only one alien species was detected. The clear separation of Alien and native species along the river might have been due to environmental conditions we measured (water temperature, $\mathrm{pH}$ and sediment TN), but other factors may have been influential. In addition, the lack of a replicate thermal river, where we could have repeated our observations of the potential links between, say, water temperature and macrophyte composition limits our ability to make generalisations from our findings. Nonetheless, the role of temperature does seem likely to have been responsible for at least some of the upversus downstream differences that we observed

Contrary to our second hypothesis, the species composition of the seed bank did not reflect that of the vegetation. Alien species had consistently fewer seeds in the sediment samples compared to natives along the river, while natives had fewer seeds in the 
TABLE 1 Species found in the vegetation plots and seed bank samples in the two (upstream and downstream) sections of the river. Alien species are highlighted with grey. NPlot = number of plots where the species occurred in the vegetation; \% = average cover of the species in the plots where they occurred; NSamp = number of samples from which the species germinated; NSeed = total number of germinated seedlings of the species; $n=$ total number of plots and samples. Classification of life forms follows Hutchinson (1975)

\begin{tabular}{|c|c|c|c|c|c|c|c|c|}
\hline \multirow[b]{2}{*}{ Species } & \multicolumn{2}{|c|}{ Upstream vegetation } & \multicolumn{2}{|l|}{$\begin{array}{l}\text { Downstream } \\
\text { vegetation }\end{array}$} & \multicolumn{2}{|c|}{ Upstream seed bank } & \multicolumn{2}{|c|}{ Downstream seed bank } \\
\hline & NPlot $(n=10)$ & $\%$ & NPlot $(n=10)$ & $\%$ & NSamp $(n=10)$ & NSeed & NSamp $(n=10)$ & NSeed \\
\hline
\end{tabular}

Planophyta

Pleuston s.l.

Hydrocharis morsus-ranae

Lemna minor

Lemna minuta

Lemna trisulca

Ceratophyllum demersum

Riccia fluitans

Rhizophyta

Hyphydates

Cabomba caroliniana

Chara vulgaris

Myriophyllum spicatum

Najas minor

Potamogeton lucens

Utricularia vulgaris

Vallisneria gigantea

Ephydates

Nuphar lutea

Nymphaea alba

Nymphaea lotus

Nymphaea rubra

Potamogeton nodosus

Salvinia natans

Spirodela polyrhiza

Hyperhydates (Helophytes)

Alisma plantago-aquatica

Bacopa crenata

Berula erecta

Carex spp.

Ceratopteris thalictroides

Glyceria maxima

Juncus articulatus

Juncus effusus

Juncus inflexus

Lysimachia vulgaris

Lythrum salicaria

Phragmites australis

Rotala rotundifolia

Schoenoplectus lacustris

Typha angustifolia

$\begin{array}{cccc} & 10 & 19.7 & \\ & 1 & 30 & 2 \\ 0.5 & 9 & 9.2 & \\ 0.5 & & & \\ & 10 & 71.6 & \\ 0.5 & & & \end{array}$

18

8

76

1

1

1

31.5

9

58

$\begin{array}{rr}2 & 3 \\ 1 & 3 \\ 5 & 12 \\ 3 & 3\end{array}$

0.5

47.5

2

3

7.2

5

40.6

31.7

8

9

13

9

38

8

37

2

3

0.5

10

11.5

2

2

3

6

1

1

0.5

$\begin{array}{lll}2.8 & 1 & 2\end{array}$

1

1

3

4

3

3

4

7

9

32

0.5

1

$10 \quad 15 \quad 9$

$0.5 \quad 3$

37.3

8

3.8

2

10

2

8.52 
TABLE 1 (Continued)

\begin{tabular}{|c|c|c|c|c|c|c|c|c|}
\hline \multirow[b]{2}{*}{ Species } & \multicolumn{2}{|c|}{ Upstream vegetation } & \multicolumn{2}{|l|}{$\begin{array}{l}\text { Downstream } \\
\text { vegetation }\end{array}$} & \multicolumn{2}{|c|}{ Upstream seed bank } & \multicolumn{2}{|c|}{ Downstream seed bank } \\
\hline & NPlot $(n=10)$ & $\%$ & NPlot $(n=10)$ & $\%$ & NSamp $(n=10)$ & NSeed & NSamp $(n=10)$ & NSeed \\
\hline Calystegia sepium & 10 & 0.7 & 1 & 0.5 & & & 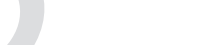 & \\
\hline Cyperus fuscus & & & & & & & 1 & 1 \\
\hline Lolium perenne & 1 & 3 & & & & & & \\
\hline Poa trivialis & 1 & 2 & & & & & & \\
\hline Potentilla reptans & 1 & 0.5 & & & & & & \\
\hline Ranunculus repens & & & & & & & 1 & 1 \\
\hline
\end{tabular}

upstream plots compared to the downstream plots. These findings strongly suggest that seed banks played a secondary role in the reproduction of alien species at our study site. Although we confirmed that native species were able to form a seed bank, we assume that if natives were to germinate in the upstream section, they could be suppressed by the more competitive alien species, and therefore the seed bank of natives is slowly being depleted.

\subsection{Vegetation and seed-bank characteristics in relation to environmental conditions}

The RDA analyses revealed significantly different species compositions in the upstream and downstream plots. The two sections were mainly distinguished by environmental factors such as water temperature and conductivity, as well as sediment TN (Figure 3). Alien species were found to be dominant in the upstream plots, where the water temperature was still high due to the proximity of the thermal lake. These alien species are of tropical/subtropical origin within their native ranges and are supposedly characterised by considerably higher temperature optima compared to native species (see, e.g. Hussner, 2012). The tropical and subtropical species include Bacopa crenata, Cabomba caroliniana, Ceratopteris thalictroides, Lemna minuta, Nymphaea lotus, Nymphaea rubra, Rotala rotundifolia and Vallisneria gigantea.

\subsection{Vegetation and seed-bank characteristics}

In this study, we detected far fewer species in the seed bank compared to other freshwater studies (Boedeltje et al., 2003; Yang \& Li, 2013), suggesting that seed banks play a secondary role in maintaining the diversity of aquatic plant communities in these thermal waters. The role of seed banks in aquatic plant communities is debated. Although it has been shown that most species are able to produce seeds, vegetative reproduction among aquatic plants is more frequent than sexual reproduction (Grace, 1993). Nevertheless, seed banks might play an important role in population maintenance (Hong, Liu, Shi, \& Zhang, 2012; Kaplan, Šumberová, Formanová, \& Ducháček, 2014; Strazisar, Koch, Dutra, \& Madden, 2013), especially where the longevity of asexual plant parts is shorter than that of their seeds (Li, 2014).

Although we recorded a low Sørensen similarity score for the seed bank and vegetation (the value in the alien-dominated upstream section was close to zero), this pattern is not seen only in rivers whether thermal or otherwise. Compared to our results, similarity in the species composition of the vegetation and the seed bank is generally higher in wetlands: for example, Sørensen similarity values of 0.3-0.4 were reported by Yang and Li (2013) in wetlands on the Yangtze River floodplain. However, this value can be as high as 0.5 0.7 in the case of terrestrial grasslands (Hopfensperger, 2007).

The low similarity scores between the seed bank and the vegetation found in this study may be a result of a variety of factors. First, low similarity values might be owing to small or non-existent seed banks of the dominant species. We detected persistent seed banks only in the case of native species, such as Chara vulgaris, Nymphaea alba, Typha angustifolia, Najas minor, Urtica dioica and Juncus spp. Limited seed persistence is also indicated by the low overall seed density in the deeper sediment layers. Second, seed-bank samples contained large quantities of seeds of riparian plants, which had been transported by the river and eventually sank to the bottom. For example, Typha angustifolia and Lythrum salicaria were abundant in the seed bank but were present only in the vegetation of the riverbank. Similar results were found by Boedeltje et al. (2003) for Lythrum salicaria. Third, a higher sampling intensity would have led to the detection of more species in the seed banks. We think this is unlikely because Brock, Theodor, and O' Donnell (1994) suggested 10 samples per site is a substantial effort for studies of wetland seed banks, and this was equivalent to the effort in our study (10 samples per section). Finally, dispersion and buoyancy of seeds from remote areas can result in low similarity values, implying that seeds of common riverbank species immediately sink when released on the water 
TABLE 2 Vegetation and seed-bank characteristics and Sørensen similarity of vegetation and seed bank of studied aquatic plant communities (mean \pm SE). Significant differences between the upstream and downstream plots were obtained by one-way ANOVA and Tukey's test

\begin{tabular}{|c|c|c|c|c|}
\hline & Upstream plots & Downstream plots & $F_{1,18}$ & $p$ \\
\hline \multicolumn{5}{|l|}{ Vegetation } \\
\hline \multicolumn{5}{|l|}{ Species number } \\
\hline Total & $7.00 \pm 0.76$ & $7.20 \pm 0.87$ & 4.28 & n.s. \\
\hline Alien & $3.70 \pm 0.42$ & $1.10 \pm 0.10$ & 81.00 & $* * *$ \\
\hline Native & $3.30 \pm 0.39$ & $6.10 \pm 0.87$ & 9.25 & $* *$ \\
\hline Hydrophytes & $2.80 \pm 0.67$ & $4.80 \pm 0.20$ & 7.96 & $*$ \\
\hline Alien & $2.2 \pm 0.32$ & $1.0 \pm 0.0$ & 13.5 & $* *$ \\
\hline Native & $0.6 \pm 0.4$ & $3.8 \pm 0.2$ & 51.2 & $* * *$ \\
\hline Helophytes & $4.20 \pm 0.41$ & $2.40 \pm 0.76$ & 0.029 & n.s. \\
\hline Alien & $1.5 \pm 0.26$ & $0.1 \pm 0.1$ & 23.83 & $* * *$ \\
\hline Native & $2.7 \pm 0.26$ & $2.3 \pm 0.76$ & 0.24 & n.s. \\
\hline \multicolumn{5}{|l|}{ Cover (\%) } \\
\hline Total & $99.34 \pm 7.11$ & $160.52 \pm 10.47$ & 23.36 & $* * *$ \\
\hline Alien & $80.47 \pm 6.45$ & $11.27 \pm 4.23$ & 80.29 & $* * *$ \\
\hline Native & $18.87 \pm 2.46$ & $149.25 \pm 9.53$ & 175.36 & $* * *$ \\
\hline Hydrophytes & $79.35 \pm 7.02$ & $122.54 \pm 14.91$ & 6.86 & * \\
\hline Alien & $76.81 \pm 6.16$ & $11.26 \pm 4.22$ & 76.92 & $* * *$ \\
\hline Native & $2.54 \pm 2.00$ & $111.28 \pm 12.45$ & 74.29 & $* * *$ \\
\hline Helophytes & $19.99 \pm 2.04$ & $37.98 \pm 8.49$ & 4.23 & n.s. \\
\hline Alien & $3.66 \pm 1.25$ & $0.01 \pm 0.01$ & 8.4 & $* *$ \\
\hline Native & $16.33 \pm 1.63$ & $37.97 \pm 8.50$ & 6.24 & $*$ \\
\hline Shannon diversity & $1.02 \pm 0.19$ & $1.65 \pm 0.11$ & 7.56 & $*$ \\
\hline \multicolumn{5}{|l|}{ Seed bank } \\
\hline \multicolumn{5}{|l|}{ Species number ${ }^{a}$} \\
\hline Total & $2.80 \pm 0.32$ & $6.10 \pm 0.51$ & 54.45 & $* * *$ \\
\hline Alien & $0.30 \pm 0.21$ & $0 \pm 0$ & 1.97 & n.s. \\
\hline Native & $2.50 \pm 0.22$ & $6.10 \pm 0.504$ & 44.46 & $* * *$ \\
\hline Hydrophytes & $2.00 \pm 0.21$ & $3.10 \pm 0.41$ & 5.76 & $*$ \\
\hline Alien & $0 \pm 0$ & $0 \pm 0$ & - & - \\
\hline Native & $2.0 \pm 0.21$ & $3.10 \pm 0.41$ & 5.76 & * \\
\hline Helophytes & $0.80 \pm 0.29$ & $3.00 \pm 0.26$ & 32.09 & $* * *$ \\
\hline Alien & $0.30 \pm 0.21$ & $0 \pm 0$ & 1.97 & n.s. \\
\hline Native & $0.5 \pm 0.22$ & $3.00 \pm 0.26$ & 53.57 & $* * *$ \\
\hline \multicolumn{5}{|c|}{ Seed density (seeds $/ \mathrm{m}^{2}$ ) } \\
\hline Total & $712.30 \pm 143.48$ & $1289.10 \pm 204.33$ & 5.33 & $*$ \\
\hline Alien & $31.20 \pm 22.19$ & $0 \pm 0$ & 0.80 & n.s. \\
\hline Native & $681.10 \pm 140.61$ & $1289.00 \pm 204.34$ & 5.79 & * \\
\hline Hydrophytes & $592.70 \pm 119.06$ & $722.50 \pm 191.06$ & 0.33 & n.s. \\
\hline Alien & $0 \pm 0$ & $0 \pm 0$ & - & - \\
\hline Native & $592.70 \pm 119.06$ & $722.50 \pm 191.06$ & 0.33 & n.s. \\
\hline Helophytes & $109.20 \pm 55.05$ & $582.00 \pm 95.73$ & 18.32 & $* * *$ \\
\hline Alien & $31.20 \pm 70.19$ & $0 \pm 0$ & 1.97 & n.s. \\
\hline Native & $77.98 \pm 145.53$ & $582.00 \pm 95.73$ & 22.5 & $* * *$ \\
\hline Shannon diversity & $0.81 \pm 0.1$ & $1.43 \pm 0.11$ & 17.3 & $* * *$ \\
\hline Sørensen similarity & $0.04 \pm 0.02$ & $0.11 \pm 0.02$ & 10.0653 & $*$ \\
\hline
\end{tabular}

${ }^{a}$ Species numbers in the seed bank are given for five cores pooled together from the same plot. ${ }^{*} p<.05 ;{ }^{* *} p<.01 ;{ }^{* * *} p<.001 ;$ n.s. $=$ not significant. 


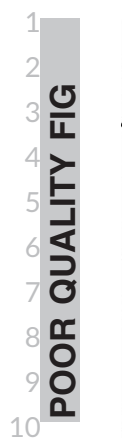
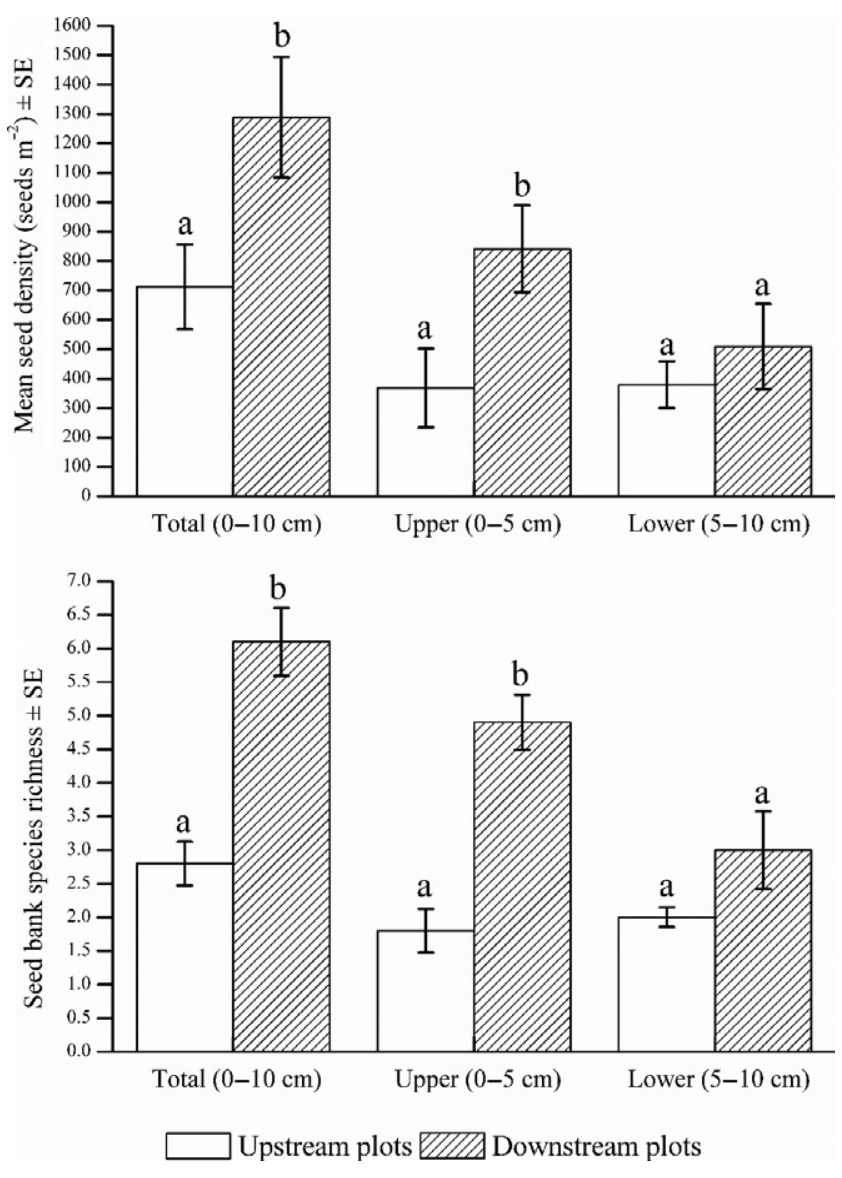

FIGURE 4 Mean seed density and species richness of the sediment seed bank in the whole profile $(0-10 \mathrm{~cm})$ and the upper $(0-5 \mathrm{~cm})$ and lower $(5-10 \mathrm{~cm})$ layers in upstream and downstream plots. Values are means \pm standard errors. Different letters indicate significant differences ( $t$-test, $p<.05$ ) between the upstream and downstream sections

or float for a very long time instead of sinking to the sediment. Although we lack comparative data on the seed buoyancy of aquatic species, Johansson, Nilsson, and Nilsson (1996) revealed that the proportion of species that float longer than 2 days was higher in river-bank flora than in other habitats. The difference between seed densities in up- and downstream reaches could also have been a consequence of temperature differences. High temperatures not only decrease the compositional similarity of the seed bank and vegetation but can also limit seed production and seed germination in native species (as suggested by the results of the Spearman rank correlation).

\subsection{Conclusions and conservation importance}

A considerable amount of seeds of native species was found downstream relative to the upstream reach, which was mainly inhabited by aliens with a higher temperature optimum. Natives were largely confined to the cooler downstream reaches, and hence were rare in the upstream seed bank. The alien-dominated upstream river section had a lower and less species-rich seed-bank density, but the seeds of alien plants were scarcer and less speciose downstream tan in the upstream reach. These results suggest that the seed bank plays a secondary role compared to vegetative reproduction, at least for alien species, and that vegetative reproduction might be a predominant means of in maintaining their populations in thermal rivers. Where such populations are established as the result of a single event, the dominance of a single clone can result in genetic homogeneity (Wang, Wang, Guo, \& Barrett, 2005). This homogeneity is especially risky in the case of heterostylous aquatic plants, in which the same species develops different morphs (with different positions of sexual organs inside the flower) to avoid self-pollination. Heterostyly appears often among aquatic plant species such as Nymphaeaceae and Pontederiaceae. Single-clone populations with only one form of floral morphology often fail to produce viable seeds (Shibayama \& Kadono, 2003), and their persistence is dependent upon vegetative reproduction. However, the species included in this study have not been shown to be heterostylous, and the presence of a single clone - instead of genetic heterogeneity in the population - may be the cause of low seed production and germination by alien species.

Our results suggest that for effective conservation management, the clearing of alien species from the vegetation would prove to be sufficient means for controlling them, as their renewal from the seed bank is very unlikely. Tropical and subtropical alien macrophytes are able to establish and maintain viable populations in thermal rivers such as the one that we studied, but the invaders did not build persistent seed banks, and thus it is unlikely that they could spread to non-thermal temperate waterbodies. Although it cannot be excluded that they can disperse to such non-thermal habitats (e.g. via zoochory by waterfowl), the lack of persistent seed banks would limit their ability to sustain population over the long term. However, we found that the alien macrophytes could alter both the above-ground species composition and seed banks in upstream reach of our study site, and probably constrained re-establishment of native species from the seed bank. This difference between river sections may require suite-specific management strategies of conservation of native plants and control of their alien counterparts.

\section{ACKNOWLEDGMENTS}

The authors would like to thank András Kelemen and Zsolt Végvári (University of Debrecen) and two anonymous reviewers for their useful comments as well as Joan P. Mattia for improving the language of the manuscript. We thank Mihály Braun and Enikő Heim (Hertelendi Laboratory of Environmental Studies of the Hungarian Academy of Sciences) for their help in the analytical measures, Tímea Bodor for her contribution to the sample preparation and Endre Bajka for his contributions to the field sampling. This research was supported by the European Union and the State of Hungary, cofinanced by the European Social Fund in the framework of TÁMOP4.2.4.A/2-11/1-2012-0001 'National Excellence Program' and financially supported by the GINOP-2.3.2-15-2016-00019 project. BAL was supported by OTKA PD120775 Grant. OV was supported by 
the Bolyai János Research Scholarship of the Hungarian Academy of Sciences. The instrumental and infrastructural support of OTKA 4 K108992 Grant is also highly appreciated.

\section{REFERENCES}

Boedeltje, G., Bakker, J. P., \& ter Heerdt, G. N. J. (2003). Potential role of propagule banks in the development of aquatic vegetation in backwaters along navigation canals. Aquatic Botany, 77, 53-69.

Boedeltje, G., ter Heerdt, G. N. J., \& Bakker, J. P. (2002). Applying the seedling-emergence method under waterlogged conditions to detect the seed bank of aquatic plants in submerged sediments. Aquatic Botany, 72, 121-128.

Bonis, A., \& Lepart, J. (1994). Vertical structure of seed banks and the impact of depth of burial on recruitment in two temporary marshes. Vegetatio, 112, 127-139.

Boros, Á. (1937). Magyarországi hévizek felsőbbrendü növényzete [In Hungarian]. Botanikai Közlemények, 34, 85-118.

Bossuyt, B., \& Honnay, O. (2008). Can the seed bank be used for ecological restoration? An overview of seed bank characteristics in European communities. Journal of Vegetation Science, 19, 875-884.

Brochet, A. L., Guillemain, M., Fritz, H., Gauthier-Clerc, M., \& Green, A. J. (2009). The role of migratory ducks in the long-distance dispersal of native plants and the spread of exotic plants in Europe. Ecography, 32, 919-928.

Brock, M. A., Theodor, K., \& O' Donnell, L. (1994). Seed-bank methods for Australian wetlands. Australian Journal of Marine and Freshwater Research, 45, 483-493.

Brown, A., \& Oosterhuis, C. (1981). The role of buried seeds in coppice woods. Biological Conservation, 21, 19-38.

Brunel, S. (2009). Pathway analysis: Aquatic plants imported in 10 EPPO countries. EPPO Bulletin, 39, 201-213.

Champion, P. D., Clayton, J. S., \& Hofstra, D. E. (2010). Nipping aquatic plant invasions in the bud: Weed risk assessment and the trade. Hydrobiologia, 656, 167-172.

Espinar, J. L., Díaz-Delgado, R., Bravo-Utrera, M. A., \& Vilà, M. (2015). Linking Azolla filiculoides invasion to increased winter temperatures in the Doñana marshland (SW Spain). Aquatic Invasions, 10, 17-24.

Fenner, M., \& Thompson, K. (2005). The ecology of seeds. Cambridge: Cambridge University Press.

Gioria, M., \& Pyšek, P. (2016). The legacy of plant invasions: Changes in the soil seed bank of invaded plant communities. BioScience, 66, ???-???. doi:10.1093/biosci/biv165

Grace, J. B. (1993). The adaptive significance of clonal reproduction in angiosperms: An aquatic perspective. Aquatic Botany, 44, 159-180.

Grillas, P., Garcia-Murillo, P., Geertz-Hansen, O., Marbá, N., Montes, C., Duarte, C. M., et al. (1993). Submerged macrophyte seed bank in a Mediterranean temporary marsh: Abundance and relationship with established vegetation. Oecologia, 94, 1-6.

Haag, R. W., \& Gorham, P. R. (1977). Effects of thermal effluents on standing crop and net production of Elodea canadensis and other submerged macrophytes in Lake Wabamun, Alberta. Journal of Applied Ecology, 14, 835-851.

Hong, J., Liu, S., Shi, G., \& Zhang, Y. (2012). Soil seed bank techniques for restoring wetland vegetation diversity in YeyahuWetland, Beijing. Ecological Modelling, 42, 192-202.

Hopfensperger, K. N. (2007). A review of similarity between seed bank and standing vegetation across ecosystems. Oikos, 116, 1438-1448.

Hussner, A. (2012). Alien aquatic plant species in European countries. Weed Research, 52, 297-306.

Hussner, A. (2014). Long-term macrophyte mapping documents a continuously shift from native to non-native aquatic plant dominance in the thermally abnormal River Erft (North Rhine-Westphalia, Germany). Limnologica, 48, 39-45.
Hussner, A., \& Lösch, R. (2005). Alien aquatic plants in a thermally abnormal river and their assembly to neophyte-dominated macrophyte stands (River Erft, Northrhine-Westphalia). Limnologica, 35, 18-30.

Hutchinson, G. E. (1975). A treatise on limnology. Vol III. Limnological botany. New York: John Wiley \& Sons.

Johansson, M., Nilsson, C., \& Nilsson, E. (1996). Do rivers function as corridor for plant dispersal? Journal of Vegetation Science, 7, 593-598.

Kaplan, Z., Šumberová, K., Formanová, I., \& Ducháček, M. (2014). Reestablishment of an extinct population of the endangered aquatic plant Potamogeton coloratus. Aquatic Botany, 119, 91-99.

$\mathrm{KSH}$. (2014). Retrieved from http://www.ksh.hu/docs/hun/xstadat/xs tadat_evkozi/e_met002.html (accessed: 18. 10. 2016)

Leck, M. A., \& Simpson, R. L. (1987). Seedbank of a freshwater tidal wetland: Turnover and relationship to vegetation change. American Journal of Botany, 74, 360-370.

Legendre, P., \& Legendre, L. (1998). Numerical ecology. Amsterdam: Elsevier.

Li, W. (2014). Environmental opportunities and constraints in the reproduction and dispersal of aquatic plants. Aquatic Botany, 118, 62-70.

Lovassy S. (1908) A keszthelyi Hévíz tropikus tündérrózsái. A Balaton flórája 2. szakasz függeléke, Magyar Földrajzi Társaság BalatonBizottsága, Budapest.

Lukács, K. (1943). A Balatonvidék földrajza kétszáz év előtt. Bél Mátyás "Notitia comitatuum Veszprimiensis, Simighiensis et Szaladiensis" c. kéziratának fordítása és ismertetése. Magyar Biológiai Kutató Intézet munkái, 15, 220-300.

Lukács, B. A., Mesterházy, A., Vidéki, R., \& Király, G. (2014). Alien aquatic vascular plants in Hungary (Pannonian ecoregion): Historical aspects, data set and trends. Plant Biosystems. https://doi.org/10.1080/ 11263504.2014 .987846$.

Lukács, B. A., Tóthmérész, B., Borics, G., Várbíró, G., Juhász, P., Kiss, B., et al. (2015). Macrophyte diversity of lakes in the Pannon Ecoregion (Hungary). Limnologica, 53, 74-83.

Ma, M., Zhou, X., \& Du, G. (2010). Role of soil seed bank along a disturbance gradient in an alpine meadow on the Tibet plateau. Flora, 205, 128-134.

Maki, K., \& Galatowitsch, S. (2004). Movement of invasive aquatic plants into Minnesota (USA) through horticultural trade. Biological Conservation, 118, 389-396.

McMillan, C. (1988). The seed reserve of Halophila decipiens Ostenfeld (Hydrocharitaceae) in Panama. Aquatic Botany, 31, 177-182.

MSZ EN 14672. (2006). Characterization of sludges. Determination of total phosphorus. Budapest: Magyar Szabványügyi Hivatal

MSZ EN 16168. (2013). Sludge, treated biowaste and soil. Determination of total nitrogen using dry combustion method. Budapest: Magyar Szabványügyi Hivatal.

Nicolet, P., Biggs, J., Fox, G., Hodson, M. J., Reynolds, C., Withfield, M., et al. (2004). The wetland plant and macroinvertebrate assemblages of temporary ponds in England and Wales. Biological Conservation, 120, 265-282.

Poiani, K. A., \& Johnson, W. C. (1988). Evaluation of the emergence method in estimating seed bank composition of prairie wetlands. Aquatic Botany, 32, 91-97.

Poiani, K. A., \& Johnson, W. C. (1989). Effect of hydroperiod on seedbank composition in semipermanent prairie wetlands. Canadian Journal of Botany, 67, 856-864.

Šajna, N., Haler, M., Škornik, S., \& Kaligarič, M. (2007). Survival and expansion of Pistia stratiotes L. in a thermal stream in Slovenia. Aquatic Botany, 87, 75-79.

Sand-Jensen, K., Riis, T., Vestergaard, O., \& Larsen, S. E. (2000). Macrophyte decline in Danish lakes and streams over the past 100 years. Journal of Ecology, 88, 1030-1040.

Santamaria, L., \& van Vierssen, W. (1997). Photosynthetic temperature responses of fresh- and brackish-water macrophytes: A review. Aquatic Botany, 58, 135-150. 
Shibayama, Y., \& Kadono, Y. (2003). Floral morph composition and pollen limitation in the seed set of Nymphoides indica populations. Ecological Research, 18, 725-737.

Strazisar, T., Koch, M. S., Dutra, E., \& Madden, C. J. (2013). Ruppia maritima L. seed bank viability at the Everglades-Florida Bay ecotone. Aquatic Botany, 111, 26-34.

Szabó, I. (2002). Melegvízi növényfajok Hévíz és Keszthely vizeiben. Botanikai Közlemények, 89, 105-115.

ter Braak C.J.F. \& Šmilauer P. (2012) Canoco reference manual and user's guide: software for ordination, version 5.0. Ithaca: Microcomputer Power.

ter Heerdt, G. N. J., Verweij, G. L. R., Bekker, R. M., \& Bakker, J. P. (1996). An improved method for seed bank analysis: Seedling emergence after removing the soil by sieving. Functional Ecology, 10, 144-151.

Terrados, J. (1993). Sexual reproduction and seed banks of Cymodocea nodosa (Ucria) Ascherson meadows on the southeast Mediterranean coast of Spain. Aquatic Botany, 46, 293-299.

Thompson, K., Hodgson, J. G., \& Rich, T. C. G. (1995). Native and alien invasive plants: More of the same? Ecography, 18, 390-402.

Valkó, O., Tóthmérész, B., Kelemen, A., Simon, E., Miglécz, T., Lukács, B. A., et al. (2014). Environmental factors driving seed bank diversity in alkali grasslands. Agriculture, Ecosystems and Environment, 182, 80-87.

Wang, Y., Wang, Q. F., Guo, Y. H., \& Barrett, S. C. (2005). Reproductive consequences of interactions between clonal growth and sexual reproduction in Nymphoides peltata: A distylous aquatic plant. New Phytologist, 165, 329-336.
Williams, P., Whitfield, M., Biggs, J., Bray, S., Fox, G., Nicolet, P., et al. (2004). Comparative biodiversity of rivers, streams, ditches and ponds in an agricultural landscape in Southern England. Biological Conservation, 115, 329-341.

Yang, D., \& Li, W. (2013). Soil seed bank and aboveground vegetation along a successional gradient on the shores of an oxbow. Aquatic Botany, 110, 67-77.

Zar, J. H. (1999). Biostatistical analysis. New Jersey: Prentice-Hall.

\section{SUPPORTING INFORMATION}

Additional Supporting Information may be found online in the supporting information tab for this article.

How to cite this article: Vojtkó AE, Mesterházy A, Süveges K, Valkó O, Lukács BA. Changes in sediment seed-bank composition of invaded macrophyte communities in a thermal river. Freshwater Biol. 2017;00:1-12. https://doi.org/10.1111/ fwb.12922 